\title{
Thin layer chromatographic detection of some common antioxidants
}

\author{
By M.E. Komaitis
}

Department of Agricultural Industries, Agricultural University of Athens, lera Odos 75, Athens 118 55, Greece.

\section{RESUMEN}

Detección por cromatografía en capa fina de algunos antioxidantes comunes.

Se describe un método para la determinación cualitativa de 3-t-butil-4-hidroxianisol, 2,6-di-t-butil-4-hidroxitolueno, galato de propilo, galato de octilo y galato de dodecilo en aceites y grasas comestibles. El método está basado en el desarrollo de un derivado coloreado específico a partir de la reacción de los antioxidantes con la $\mathrm{N}, \mathrm{N}$-dimetil-p-fenilenediamina en presencia de agente oxidante suave en solución alcalina.

El método dió buenos resultados y puede llevarse a cabo fácilmente con los medios existentes en la mayoria de los laboratorios analíticos.

PALABRAS-CLAVE: Aceite comestible - Antioxidante (detección) - Cromatografía en capa fina - Grasa comestible.

\section{SUMMARY}

Thin layer chromatographic detection of some common antioxidants.

A method is described for the qualitative determination of butylated hydroxyanisole, butylated hidroxytoluene, propyl gallate, octyl gallate and dodecyl gallate in edible fats and oils. The method is based on the development of a specific colour derived from the reaction of the antioxidants with N,N-dimethyl-p-phenylenediamine in the presence of a mild oxidizing agent in alkaline solution.

The method gave good results and can be carried out easily with facilities existing in most analytical laboratories.

KEY-WORDS: Antioxidant (detection) - Edible fat - Edible oil - Thin layer chromatography.

\section{INTRODUCTION}

Antioxidants commonly found in fats and oils include butylated hydroxyanisole (BHA), butylated hydroxytoluene $(\mathrm{BHT})$ and gallates, mainly propyl (PG), octyl (OG) and dodecyl (DG).

The widespread use of antioxidants in foodstuffs have resulted in the development of numerous techniques for their qualitative and quantitative determination.

Usually, a food extract, steam distillate or fat solution is treated with a specific reagent to pro- duce a colour with the antioxidant. The commonly used spray reagents are 2,6-dichloroquinone-4chloroimide (Gibbs reagent) in ethanol and phosphomolybdic acid in methanol (1).

The present work is concerned with a new spraying reagent. This is a specific reagent that was used by Komaitis and Kapel (2) for the spectrophotometric determination of BHA in edible fats and oils.

The color development is based on the reaction of $p$-phenylenediamines with phenols in the presence of an oxidizing reagent (3); Official Standardized and Recommended Methods of Analysis (4).

\section{MATERIALS AND METHODS}

\subsection{Reagents and Materials}

The BHT and BHA reference standards were obtained from SIGMA, PG from $B D H$ and $O G$ and DG from FLUKA.

Thin layer chromatography sheets were coated with silica gel $60 \mathrm{~F}_{254}$ and were obtained from MERCK.

Sodium hydrogen carbonate was used in $5 \%$ $w / v$ aqueous solution.

$\mathrm{N}, \mathrm{N}$-dimethyl-p-phenylenediamine oxalate solution. $0.17 \mathrm{~g}$ of this reagent was dissolved in 100 $\mathrm{ml}$ water under a nitrogen atmosphere. water.

Potassium ferricyanide, $8 \% \mathrm{w} / \mathrm{v}$ in distilled

Spraying reagent (DPDA).

$2 \mathrm{ml}$ of sodium hydrogen carbonate solution, $2 \mathrm{ml} \mathrm{N}, \mathrm{N}$-dimethyl-p-phenylenediamine solution and $2 \mathrm{ml}$ potassium ferricyanide solution were pipetted in a $25 \mathrm{ml}$ volumetric flask and the solution was made up to the mark with distilled water. 
Table 1

$R_{f}$ values and spot colours.

\begin{tabular}{|c|c|c|c|c|}
\hline \multirow{3}{*}{ Antioxidant } & \multicolumn{3}{|c|}{$R_{f}$} & \multirow{3}{*}{$\begin{array}{l}\text { Colour of } \\
\text { spots }\end{array}$} \\
\hline & \multicolumn{2}{|c|}{ Developing } & \multirow{2}{*}{$\begin{array}{c}\text { solvent } \\
\text { c }\end{array}$} & \\
\hline & a & $\mathrm{b}$ & & \\
\hline & & & & - \\
\hline PG & 0.10 & 0.25 & 0.58 & brownish grey \\
\hline OG & 0.16 & 0.38 & 0.65 & " " \\
\hline DG & 0.25 & 0.45 & 0.67 & " " " \\
\hline BHA & 0.60 & 0.85 & 0.90 & brownish \\
\hline BHT & 0.90 & 0.97 & 0.98 & green with grey rim \\
\hline
\end{tabular}

\subsection{Procedure}

\subsubsection{Extraction}

A known quantity of fat $(10 \mathrm{~g})$ was dissolved in $100 \mathrm{ml}$ of hexane. The solution was extracted with four $25 \mathrm{ml}$ portions of $80 \%$ ethanol followed by eight $25 \mathrm{ml}$ portions of acetonitrile. The combined extracts were evaporated to $2 \mathrm{ml}$ using a rotary evaporator under reduced pressure at $40^{\circ} \mathrm{C}$.

\subsubsection{Chromatography}

$2 \mu \mathrm{l}$ were applied to the thin layer chromatography plates and developed in various solvents. After drying in the air, the plates were sprayed with DPDA solution and heated for $1 \mathrm{~min}$.

\section{RESULTS AND DISCUSSION}

The method was tested with pure solutions of antioxidants. Standards of each antioxidant were prepared and examined separately and in admixture.

Known quantities of fats or oils were fortified with $\mathrm{BHA}, \mathrm{BHT}, \mathrm{PG}, \mathrm{OG}, \mathrm{DG}$ and after the extraction, the antioxidants were tried in various developing solutions.

a. Petroleum ether-benzene-glacial acetic acid, 40:40:20 v/v.

b. Petroleum ether-benzene-ethyl acetate-glacial acetic acid, 40:40:25:4 v/v.

c. Chloroform-methanol-glacial acetic acid, 90:10:2 v/v.

The results are shown in Table 1.
The method was also applied to high fat foods such as vegetable oils, butter and lard and no interference was observed. The results were very good.

From the aforementioned it is obvious that this method offers another alternative for the qualitative determination of BHA, BHT, PG, OG, DG in fats and oils.

The method gave good results and can be carried out easily with facilities existing in most analytical laboratories.

\section{REFERENCES}

1. BS 684 Section 2.33 Antioxidants, 1983.

2. Komaitis, M. E. and Kapel, M.- "Spectrophotometric determination of BHA in edible fats and oils".- J. Am. Oil Chemists' Soc. 62 (1985) 1371-1372.

3. Corbett, J. F.- "Application of oxidative coupling reactions to the assay of p-phenylenediamines and phenols".- Anal. Chem. 47 (1975) 308-312.

4. "Official Standardized and Recommended Methods of Analysis".- 2nd Edition.- By Hanson, N. W., pp. 451-453.- The Society for Analytical Chemistry, London, 1973. 